\title{
ADOPTION OF NEW TECHNOLOGIES IN SMALL AND MEDIUM ENTERPRISES. CASE OF AN AUTOMATIC IN THE RETAIL PAYMENT PROCESS
}

Miguel Calderón, DBA. RoureBlau LA, Honduras

Mario Alejandro Calderón Maldonado, HNC, Honduras

Klever Figueroa, FYM Inplass, Ecuador

Liseth Pico Escobar, FYM Inplass, Ecuador

dx.doi.org/10.18374/JIMS-20-1.5

\begin{abstract}
The adoption of Information Technologies in retail leads to confrontation by small and medium-sized companies, which despite feeling that these technology adoptions are favorable, are unwilling to install them in business, especially in Central America (Albright, 2017). An evaluation of purchase times process was made comparing the conventional payment system with automation in retail points in a family business company. It was found that the automatic system requires less time from the buyer compared to the conventional system through a hypothesis test of two independent samples. It was concluded that an economic and operational evaluation is required for the adoption of the new method to obtain a better approach.
\end{abstract}

Keywords: automation, purchase process, small and medium enterprises. 